\title{
The Public Library of Science
}

\author{
Open access from the ground up
}

by Helen J. Doyle

D espite the recent spike in press coverage, conference symposia, and electronic list discussions dedicated to the subject, open-access publishing is not a new concept or a nascent revolution. Both the idea and the practice of providing free access to scholarly literature in widely available; searchable archives have a long, rich history. ${ }^{1}$ In a sense then, the current spate of international interest in open access might be seen as a number of parallel movements, which are converging and gathering momentum due to a variety of forces, both internal and external to the scholarly publishing system.

The Public Library of Science (PLoS), a relatively new player on the open access scene, is one piece of a dynamic and complex landscape of organizations, policies, beliefs, myths, constraints, and ideals about open access and scholarly publishing. As an open-access publisher and advocacy organization, PLOS is steadfast in its commitment to making the scientific and medical literature a public resource, so that anyone with access to the Internet can read and use the scientific discoveries that are generated through research largely funded with public monies.

PLOS is also unwavering in its belief that such a system will better serve the scientific community, the public, agencies that fund research, universities and research institutions, and ultimately, the scholarly publishers themselves (though not perhaps with the profit levels enjoyed by some commercial publishers). Moreover, it seems to us that there is ample money in the current system of scientific research and publishing for open access journals to thrive in a healthy, competitive publishing market, and that analysis guides our working business model.

\section{A better way to share information}

PLOS began as a grassroots movement within the scientific community, led initially by Nobel Laureate Harold Varmus, who as director of the $\mathrm{Na}$ tional Institutes of Health $(\mathrm{NIH})$ envisioned a better way to publish, disseminate, share, and use scientific discoveries. Varmus' vision was stimulated in part by the public data-sharing within the Human Genome Project, but also by the simultaneous explosion in biomedical information, the speed at which basic research was being commercialized, the globalization of science, and the growing demand by the public for information.

"PubMed Central," the digital archive of the life sciences literature (in its full text, rather than merely abstracted version)—-managed by the $\mathrm{Na}$ tional Library of Medicine-was the first product of this vision. ${ }^{2}$ All of these trends were, of course, made possible by the rise of the Internet as the dominant way people disseminate and access information. ${ }^{3}$

\section{About the author}

Helen J. Doyle is director of development and strategic alliances at the Public Library of Science, e-mail: hdoyle@plos.org 2004 Helen J. Doyle 
As a grassroots movement, PLoS aimed to catalyze change by urging individual scientists to take back control of their scholarly work by boycotting high-priced, pay-for-access journals; by stepping down from editorial boards; and by refusing to submit or to review papers for such journals. Between November 2000 and September 2001, more than 30,000 scientists throughout the world signed the PLoS Open Letter which stated in part:

\section{We support the establishment of an online public library that would provide the full contents of the published record of re- search and scholarly discourse in medicine and the life sciences in a freely accessible, fully searchable, interlinked form. Estab- lishment of this public library would vastly increase the accessibility and utility of the scientific literature, enhance scientific pro- ductivity, and catalyze integration of the disparate communities of knowledge and ideas in biomedical sciences. ${ }^{4}$}

As support for the intention of the Open Letter suggests, the movement towards open access in scientific publishing was gathering momentum, even if the boycott of commercial journals itself did not succeed. PLOS COfounders Patrick Brown (Stanford) and Michael Eisen (University of California-Berkeley) joined Varmus in setting out to prove that a top-tier, high-quality journal could turn the existing subscription model upside down by charging a reasonable fee to cover the cost of publication on the front end but keeping the journal free to all readers via the Internet on the back end. Thus, with start-up funding from the Gordon and Betty Moore Foundation and with an experienced editorial and production staff on board, PLoS became a nonprofit publisher at the end of $2002 .{ }^{5}$

PLoS was not the first to challenge the payfor-access scientific publishing community directly. BioMedCentral began publishing open access journals in 2000 , and now publishes more than 100 journals primarily in the biomedical sciences. ${ }^{6}$ The library community, which has been victimized in recent years by the unprecedented confluence of skyrocketing subscription costs and decreasing budgets, has been a vocal advocate for a different system of scholarly communication, through organizations like SPARC, which was founded in $1998 .^{7}$ Mem- bers of the public, and groups representing the public's interest, such as voluntary health agencies and public advocacy groups (including the NIH's Council of Public Representatives), have been championing the public's right to access information for a number of years. ${ }^{8}$ The landscape into which PLoS emerged as an open-access publisher at the end of 2002 was primed to be transformed.

\section{PLoS Biology}

The first issue of PLoS Biology launched in OCtober 2003 to a torrent of attention from the scientific and popular media. ${ }^{\text {As any publisher }}$ knows, however, the first issue of a journalwhich usually has a generous editorial and production lead time-matters less for its longterm sustainability than do issues that follow, which cement its reputation among readers. And, in fact, PLoS Biology must be more than a solid scientific journal; it must prove that a new open-access journal can generate topnotch papers, be supported by excellent reviewers, develop a following among diverse and discerning readers, and become a sustainable business.

The early measures of PLOS Biology's success are positive. Submissions to the journal are increasing steadily, and the papers published are covering significant new advances of the biological sciences. A handful of papers are generating the type of press coverage that only a smail portion of the published literature ever receives. ${ }^{10}$

The number of visitors to the PLoS Biology Web site is robust - the number of full-text downloads of individual articles, including synopses and other front section pieces and research articles, was over 60,000 in January 2004 . And what visitors are choosing to download is giving us interesting feedback on our content and on our readers. The front section of PLoS Biology includes features, reviews, "journal clubs," and essays that are intended to appeal broadly to scientists and to the public. Perhaps not surprisingly, these articles are downloaded more frequently than the average research article; titles from the PLoS Biology top ten list in early February such as "Economy of the Mind," "Science on the Rise in Developing Countries," "Comparative Genomics," and "In Methuselah's Mould," clearly appeal to a general audience. ${ }^{11}$

These preliminary data speak well to PLoS $B$ iology's reception within the scientific community. We hope PLoS Medicine and other PLoS 
journals soon to follow meet with similar enthusiasm from the communities they will draw from and target. And on an international level, open access continues to gain momentum among research funding agencies and policy-makers, with major new announcements of support released nearly every month. ${ }^{12}$

In order to catalyze a genuinely systemic shift in the way that scientific knowledge is disseminated, however, scientists representing multiple disciplines, nationalities, institutions, and ages must continue to voice their commitment to open-access publishing. Individual scientists can take action by submitting and reviewing papers, joining editorial boards, advocating on their campuses, and championing open-access publications.

We should be inspired by the existing examples of activism within the scientific community against the stranglehold that many payfor-access publishers have on scientists' scholarly work. For example, the Chronicle of Higher Education reported recently that:

Zvi Galil, (an editor of the Joumal of Algorithms) and dean of the school of engineering and applied science at Columbia University, said that Elsevier had increased the subscription rates unnecessarily, because production costs for the journal had not tisen recently. 'Basically, we do all the work,' Mr. Galil said, 'and the company makes all the profit.' ${ }^{13}$

And within the University of California (UC) system, the voices of frustrated scientists provided important reinforcement to the negotiating position of the UC California Digital Library with Reed Elsevier ${ }^{114}$

'It is untenable that a publisher would de facto block access of our published work even to our immediate colleagues, 'the letter states. 'Cell Press is breaking an unwritten contract with the scientific community. Being a publisher of our research carries the responsibility to make our contributions publicly available at reasonable rates. As an academic community, it is time that we reassert our values,' adds the letter, which claims that Cell Press 'values profit above its academic mission. '15

(continued on page 152)
THE ETHICS OF ELECTRONIC

INFORMATION

IN THE 21ST CENTURY

CALL FOR PROPOSALS for

\section{EEI21 - 2004 MEMPHIS}

\section{OCTOBER 13 - 16, 2004 at The University of Memphis}

A variety of proposal topics is welcome, but a special topic will be the matter of intellectual property. Attendees will include those with interests and concerns relating to the ethical use of electronic information and information technology. Professionals in the fields of information ethics, organizational management, education, health, librarianship, information science, business, communications, among others, are urged to participate in EEI21 - 2004.

Two hundred fifty-word proposals for EEI21-2004 presentations, with a brief bio of each author including current position and e-mail and postal addresses, should be sent by March 22, 2004 to: Mr. Tom Mendina, Chairman, EEI21 - 2004, tmendina@memphis.edu. Final papers, due August 2, 2004, will be 14-15 pages long (including references) doublespaced, in a standard format, and accessible as an electronic file.

\section{Information regarding EEI21}

is available at:

http://www.memphis.edu/ethics21

Papers presented at EEI21 - MEMPHIS 2002 conference will be published in spring, 2004 by McFarland \& Co., Inc., Publishers as Information Ethics in the Electronic Age: Current Issues in Africa and the World, Tom Mendina and Johannes J. Britz, editors (ISBN 0-78641742-0). 
mocracy — public, academic, school, special, governmental, and national libraries all contribute, each in their own way, to that bedrock.

"Big $A L A$ " and its divisions need to work together more than they do now. As a former divisional president, I have a number of ideas on how that can be accomplished, but they must be preceded by the fostering of a climate of enhanced trust, mutual understanding, and cooperation.

Stripling: All types of libraries rest on the fundamental values of equity, diversity, intellectual and physical access, intellectual freedom, and public participation in the interchange of ideas. By stronger collaboration and connections through ALA offices, an ALA President can overcome the "silo-ization" often seen in ALA. I will provide more opportunities for divisions to work together on common concerns, particularly 21st-century literacy, advocacy, continuing education, technology, salaries, service to youth and special populations, and recruitment.

During 2004, ALA leaders will start the process of developing another five-year action plan. I will ensure that we develop strong collaborative structures to implement the plan.

7. At the close of your term, which legacy would you like your Presidency to be remembered for?
Gorman: I would like to be remembered as an ALA leader who had a vision of libraries and librarianship that reconciled our traditional core values and services with the enthusiastic embrace of innovation-technological and otherwise - and gave all librarians and ALA members reason to be hopeful about their individual and our collective future.

Stripling: I would like to leave a legacy of community building. I will champion library efforts to build community at the local level and use those success stories to spread the word among legislators, policy makers, and the general public about the positive impact of libraries. I will showcase the extraordinary work of academic libraries in building both information and learning communities. I will also build community within ALA by improving the openness and inclusiveness of the association for all library workers and by establishing more cross-association collaboration. I will help librarians across the country to value ALA and react the way one gentleman did after reading one of my Web site blogs (www. barbstripling.net): "Now this is most interesting - an ALA presidential candidate blog. Is it time for me to renew my ALA membership?" The answer is most definitely, "Yes!"

\section{("The Public Library... "continued from page 136)}

Voices like these, those that join them, and the actions they generate will ultimately provide the final momentum needed to complete the transition to a robust, equitable, and sustainable open-access publishing system.

\section{Notes}

1. See, for example, Peter Suber's Timeline of the Open Access Movement.

2. PubMed Central, www.pubmedcentral. gov/about/intro.html.

3. "America's On-Line Pursuits," Pew Internet and American Life Project, December 2003.

4. PLos Open Letter, www plos.org/support/openletter.shtml.

5. Patrick O. Brown, Michael B. Eisen, and Harold E. Varmus, "Why PLoS Became a Publisher," PLoS Biology 1, no. 1 (2003).

6. BioMedCentral, www.biomedcentral. com/home/

7. SPARC, www.arl.org/sparc/.
8. "A Recommendation from the Council of Public Representatives," copr.nih.gov/ public_library_science.shtm.

9. See references collected at www.plos.org news/pr_2003_plos.html.

10. See references collected at www.plos.org/news/index.html $\#$ science.

11. See www.plosbiology.org/plosonline/ ?request=index-html.

12. See for example www.earlham.edu/ peters/fos/timeline.htm, www.plos.org/ about/openaccess.html\#timeline, and references therein.

13. Chronicle of Higher Education, February 9,2004 on the departure of the Board of Directors of the Journal of Algorithms from Reed Elsevier

14. Stephanie Kirchgaessner, "Companies UK: Love Affair with Reed Begins to Cool," Financial Times, February 9, 2004.

15. From a letter to UCSF faculty urging a boycott of Cell Press from Professors Peter Walter and Keith Yamamoto 